\title{
THE DOCTRINE OF RES IPSA LOQUITUR
}

\author{
Charles E. Carpenter*
}

$7 \mathrm{HE}$ law relating to res ipsa loquitur is replete with conflict, confusion and doubt. There is division of opinion as to the circumstances required for its application and still greater disagreement as to the effect to be given it. Does it merely lay the basis for a permissible inference of negligence by the jury or does it raise a presumption of negligence, and if and where it raises a presumption, what weight is to be given to it? It is not clear that where it is treated as a presumption, the court will direct a verdict for the plaintiff in the absence of rebuttal evidence by the defendant, nor is it at all clear what quantity of evidence will be required to prevent a directed verdict or how far the presumption survives the refusal to direct a verdict for the plaintiff, that is, what effect the jury shall give it. Then, too, there is much confusion with respect to the effect of pleading special acts of negligence.

It is the belief of the writer that it is wholly useless and mischievous to have a distinct doctrine of res ipsa loquitur which has the effect merely of laying the foundation for a permissible inference of negligence, and that it best serves its excuse for being if it is treated as a presumption which shifts the burden of proof to the defendant.

A brief statement of the law relating to res ipsa loquitur as found in the decisions will lay the foundation for our argument.

\section{CIRCUMSTANCES REQUIRED FOR THE APPLICATION OF RES IPSA LOQUITUR}

It is clear that the plaintiff has not produced evidence enough to make out a res ipsa loquitur case where he merely shows that he has sustained an injury. In Benedick v. Potts, ${ }^{x}$ at the trial the following facts were shown by the plaintiff: that the defendant operated a railway in a pleasure resort. Cars were hoisted up an incline to the highest point of the railway and allowed to run down by gravity upon a circular track. At one place the track passed through a tunnel about one hundred and fifty feet long. Cars and occupants while passing through this tunnel were hidden from outside observation. The cars were provided with handles to grasp during the rapid descent. The plaintiff occupied alone the rear seat of one of these

* Professor of Law, University of Southern California.

× Benedick v. Potts, 88 Md. 52, 40 Atl. 1067 (I898). 
cars during its descent. He was in the car when it entered the tunnel but not when the car emerged. He was later found inside the tunnel in an unconscious condition with a wound upon his head. The trial court upon this evidence instructed the jury that there was no legal evidence of negligence on the part of the defendant and a verdict and judgment were entered for the defendant. On appeal the supreme court sustained the trial court in this ruling, saying:

In no instance can the bare fact that an injury has happened of itself and divorced from all surrounding circumstances justify the inference that the injury was caused by negligence. ${ }^{2}$

It is a perfectly well settled principle that to entitle the plaintiff to recover in an action of this kind he must not only show that he has sustained an injury but that the defendant has been guilty of some negligence which produced the particular injury. The negligence alleged and the injury sued for must be in the relation of cause and effect. The concurrence of both and the nexus between them must exist to constitute a cause of action. ${ }^{3}$

The orthodox statement of res ipsa loquitur makes three requirements for its application. First, there must be an injury caused by the operation of an appliance or instrumentality in the exclusive possession and control of the defendant. Second, the appliance must have been such as ordinarily would not produce injury unless carelessly constructed, inspected or used. Third, the injury must have occurred without voluntary action on the part of the plaintiff. ${ }^{4}$ The basis of the presumption and that which justifies the casting of the burden of proceeding with the production of evidence on the defendant is said to be the fact that the evidence of the cause of the injury, whether culpable or innocent, is ordinarily more accessible to the defendant than it is to the plaintiff. ${ }^{5}$

The first requirement, namely, that the injury for which the plaintiff seeks recovery must have arisen from an instrumentality in the exclusive possession and control of the defendant is uniformly made. ${ }^{6} \mathrm{~A}$ res ipsa loquitur case is frequently found where objects fall from places in possession of the defendant and strike and injure the plaintiff. ${ }^{7}$ It finds frequent

2 Ibid., 55 .

3 Ibid., 54 .

4 Wigmore, Evidence (2d ed. I923) § 2509.

5 Ibid.

${ }^{6}$ Scellars v. Universal Service, 68 Cal. App. 252, 228 Pac. 879 (1924); Sullivan v. Minneapolis St. Ry. Co., I6x Minn. 45, 200 N.W. 922 (I924); Sylvia v. Newport Gas Light Co., 45 R.I. 5I5, X24 Atl. 289 (I924); Sund v. Wilmington, \& P., Traction Co., I W.W. Harr. (Del.) 328, II4 Atl. 28I (I920). See note in 53 A.L.R. $x_{495}$.

7It has been applied where the plaintiff passed under the defendant's shop window and was struck by a barrel which fell from the shop window. Byrne v. Boadle, 2 H. \& C. 722 (I863). Where the plaintiff passing along the highway under defendant's bridge was struck by a brick 
application in the cases of injuries to passengers resulting from collision between cars belonging to the same company. ${ }^{8}$ It has been applied in more doubtful cases of collision between the car of defendant in which the plaintiff was a passenger and a car not under the control and management of the defendant.9 It has been applied where a surgeon knocks out a tooth in removing tonsils ${ }^{\mathrm{x}^{\mathrm{O}}}$ or where he left a needle ${ }^{\mathrm{xx}}$ or a bandage $\mathrm{e}^{\mathrm{xz}}$ in the patient's body. The doctrine is not invoked where there is divided responsibility or where the accident is due in part to the acts of a third party over whom the defendant had no control, ${ }^{x 3}$ or where the injuring agency is under the control and management of the plaintiff. ${ }^{x_{4}}$ The mere fact that a third person, an intermeddler in no way connected with the defendant, tampered with the thing or made it defective or dangerous does not defeat the application of the rule. ${ }^{\mathrm{s}}$

The second requirement universally made is that the apparatus or appliance must have been such that in its ordinary operation no injury was to be expected unless from a careless construction, inspection or user.$^{16}$ It

which fell from a pier of the bridge. Kearney v. London Ry., L. R. 5 Q.B. $4 \mathrm{Ir}$ (1870). See also Soriero v. Pennsylvania Ry. Co., 86 N.J.L. 642,92 Atl. 604 (Igr4). It was applied where a shade around an electric light in a chandelier in defendant's music hall fell on the plaintiff. Goldstein v. Levy, 74 Misc. 463 , I32 N.Y.S. 373 (I9II). Where a radiator in the wall of a lobby of defendant's theater fell and injured the plaintiff. Carlson v. Swenson, I97 Ill. App. 4I4 (Igr6). Where an electric light fan fell upon and injured a patron in defendant's theater. Haun v. Tally, 40 Cal. App. 585, I8I Pac. 8I (xgrg). Where the roof of defendant's theater collapsed and fell on the plaintiff and others. Lyman v. Knickerbocker Theater, 5 F. (2d) 538 (C.A., D. of C. r925). Where electric wires fell in an alleyway. Gannon v. Laclede Gas Light Co, 145 Mo. 502, 46 S.W. 968,47 S.W. 907 (I898). Where the bucket of a concrete mixer dropped, Meyer v. Tobin, 82 Cal. Dec. 565,4 P. (2d) 542 (I93I). Where the walls of a building collapsed, Fox v. Bronx Amusement Co., 9 Ohio App. 426 (rgr8). Where a window pane fell, Sinkovitz v. Peters Land Co., 5 Ga. App. 788, 64 S.E. 93 (rgog); a window screen. Southwestern T. \& T. Co. v. Sheppard, I89 S.W. 799 (Tex. I916) a corner of a building fell. DeMun Estate Corp. v. Frankfort Gen. Ins. Co., I96 Mo. App. I, I87 S.W. II24 (IgI6).

${ }^{8}$ Sand Springs Park v. Schrader, 82 Okla. 244, I98 Pac. 983 (I921); Loudoun v. Eighth Avenue Railway Co., I62 N.Y. 380,56 N.E. 988 (Ig00).

9 Plumb v. Richmond Light \& R. Co., 233 N.Y. 285,135 N.E. 504 (1922). See also note in I3 L.R.A. (N.S.) 6og, 6Io.

ro Brown v. Shortlidge, 98 Cal. App. 352, 277 Pac. 134 (I929). See note to Bollenbach v. Bloomenthal, 34 I Il. 539, I 73 N.E. 670 (1930), in 26 Ill. L. Rev. $35^{\circ}$ (x93I).

II Sellers v. Noah, 209 Ala. 103, 95 So. I67 (I923).

12 Palmer v. Humiston, 87 Ohio St. 40r, ror N.E. 283 ( ${ }^{2} 9 \mathrm{r} 3$ ).

23 Loehner v. North Chicago St. Ry. Co., II6 Ill. App. 365 (Ig04).

Is White v. Spreckels, Io Cal. App. 287, Ior Pac. 920 (1909).

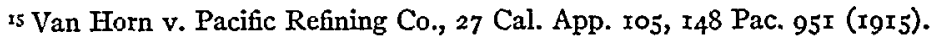

${ }^{6} 6$ Wigmore, supra note $2, \S 25 \mathrm{cg}$; see cases collected in article on Negligence, 45 C.J. I212, $\S 780$, footnote 2 . 
is not sufficient to show that the injury occurred and that it occurred through an instrumentality which was exclusively within the control and management of the defendant. The instrumentality and its operation must have been such as ordinarily would not have produced injury in the absence of negligence. It is sufficient, however, that the circumstances surrounding the accident render it more probable that the injury was due to the negligence of the defendant than otherwise. ${ }^{17}$ An injury received from the operation of an instrumentality in the exclusive control of the defendant will not always give rise to an inference of negligence and if it does not the res ipsa loquitur doctrine cannot be applied. Thus, in Piehl $v$. Albany Ry. Co. ${ }^{18}$ where a flywheel was disrupted and a portion of it cast across the street into a saloon, killing the plaintiff's intestate, it was held that a mere bursting of the flywheel was not sufficient to warrant an inference of negligence because the disruption of flywheels does frequently proceed from causes which science is unable to discover and guard against and therefore negligence is not to be inferred from such occurrence alone. The case indicates the unqualified necessity of the requirement of a set-up of facts which will warrant reasonably an inference of negligence. The exclusive control and possession of the defendant of the instrumentality of the injury is incidental to that end, and also to indicate that such exclusive control and possession on the part of the defendant makes knowledge of the facts surrounding the cause of the injury presumably more accessible to the defendant than to the plaintiff. ${ }^{19}$

A third requirement in the orthodox statement is that the injury must have occurred without voluntary action on the part of the plaintiff. ${ }^{20}$

While it is not uncommonly emphasized that the special reason or excuse for the existence of res ipsa loquitur is that since injury occurred under circumstances concerning which the defendant is in a superior position to have knowledge it is therefore fair that he should be required to produce the evidence in explanation, it is only occasionally in the cases that it is held that the doctrine cannot be invoked if the circumstances do not suggest or indicate this superior accessibility to the evidence on the part of the defendant, or, where it appears that the plaintiff has equal or superior means of information..$^{2 x}$

${ }_{17}$ Howser v. Cumberland Ry., 8o Md. I46, 30 Atl. g06 (I894); Mathews v. Chicago Ry. Co., 162 Minn. 3 I3, 202 N.W. 896 (1925).

${ }^{8}$ Piehl v. Albany Ry. Co., 30 App. Div. I66, affd. in I62 N.Y. 6I 7, 57 N.E. I122 (I900). (Igr4).

×9 For a similar case see Hughes v. Atlantic City \& Shore Ry. Co., 85 N.J.L. 212, 89 Atl. 769

20 Wigmore, supra note $2, \S 2509$.

${ }^{2 x}$ See cases collected in article on Negligence, 45 C.J. $x 205, \S 773$, footnote 46 . 
Another requirement occasionally made is that direct evidence must have been unavailable to the plaintiff in order to invoke res ipsa loquitur. Some cases have held that the rule is one of necessity, providing a substitute for direct proof of negligence only where such direct proof is unavailable, and that it can only be invoked where direct evidence is unavailable, and that unless the plaintiff presents all the testimony reasonably within his power he can derive no benefit from the doctrine. ${ }^{22}$

\section{EFFECT OF THE APPLICATION OF RES IPSA IOQUITUR}

(a) Establishes the Basis for a Permissive Inference of Negligence by the Jury. Where the plaintiff presents a res ipsa loquitur case, what effect is to be given it? The view which seems to prevail in the greater number of jurisdictions is that a res $i p s a$ case merely lays the foundation for a permissible inference by the jury of negligence on the part of the defendant. ${ }^{23}$ The proof of the accident and the injury, with attending circumstances though there is no direct evidence of the defendant's negligence or causal relation to the injury, entitles the plaintiff to go to the jury. A motion for a non-suit of the plaintiff or a directed verdict for the defendant will be denied. If the defendant does not introduce any evidence to overcome the case made for the plaintiff, the plaintiff will be entitled to have the jury consider under proper instructions whether or not the facts shown warrant them in making the inference that the defendant was guilty of the negligence which caused the injury. If the jury finds for the plaintiff that the defendant was guilty of such negligence, the verdict of the jury cannot be disturbed. Under this view the plaintiff will not be entitled to a directed verdict on the failure of the defendant to introduce evidence. This view seems to obtain in Connecticut, ${ }^{24}$ Colorado, ${ }^{25}$ Iowa, ${ }^{26}$ Michigan, ${ }^{27}$

${ }_{22}$ Bahr v. Lombard, 53 N.J.L. 233, 21 Atl. I9o, 23 Atl. I6 7 (I890); Cass v. Sanger, 77 N.J.L. 4I2, 7I Atl. II 26 (I909); Levendusky v. Empire Rubber Mfg. Co., 84 N.J.L. 698,87 Atl. $33^{8}$ (x913).

${ }^{23}$ See cases collected in note, 53 A.L.R. I494, ${ }_{5}$ II

24 Stebel v. Connecticut Co., 90 Conn. 24, 96 Atl. I7I (19r5); Ruerat v. Stevens, I I3 Conn. 333, I55 Atl. 219 (193I).

${ }^{25}$ Colorado Springs Ry. Co., v. Reese, 69 Colo. $x$, I69 Pac. 572 (Igr 7 ); but compare Velotta v. Yampa Valley Coal Co., 63 Colo. 489 , 67 Pac. 971 (x917) in which apparently a presumption is raised.

${ }^{26}$ Duncan v. Ft. Dodge Gas \& Elect. Co., I93 Iowa Ir27, I88 N.W. 865 (1922).

27 Barnowski v. Helson, 89 Mich. 523, 50 N.W. 989, (x891); Burghardt v. Detroit United Ry. Co., 206 Mich. 545, 173 N.W. 360 (1919); Fuller v. Magatti, 231 Mich. 213, 203 N.W. 868 (Ig25); Loveland v. Nelson, 235 Mich. 623, 200 N.W. 835 (I926); Kerr v. City of Detroit, 255 Mich. 446, 238 N.W. rgo (I93x).

Compare statement in 45 C.J. II94: "In Michigan the presumption of negligence arising under the rule of res ipsa loquitur has not been recognized as such in the cases; on the contrary it is frequently stated in express terms that the rule has not been adopted in this state. (Loveland v. Nelson, 235 Mich. 623, 209 N.W. 835; Fuller v. Magatti, 23I Mich. 213, 203 N.W. 


\section{Minnesota, ${ }^{28}$ New Jersey, ${ }^{29}$ North Carolina, ${ }^{30}$ Ohio, ${ }^{3 \mathrm{I}}$ and Okla- homa. ${ }^{32}$}

(b) Establishes a Presumption of Negligence. In several states, a res ipsa loquitur case is given the effect of raising a presumption. This means that the res ipsa case lays the foundation not merely for the jury's possible inference of negligence on the part of the defendant, but the jury will be required by the court to make such inference. If the plaintiff makes out a res ipsa loquitur case and the defendant does not assume his burden of going forward with evidence, the court, if it is satisfied that the plaintiff's evidence so clearly establishes a res ipsa loquitur case that a jury could not reasonably find otherwise, will direct a verdict for the plaintiff. ${ }^{33}$ If the court is not so certain that a res ipsa case has been made out, it will leave it to the jury to find if such a case exists and if such is found, a verdict will be directed for the plaintiff. Frequently the language of a court points toward a presumption, but the effect in fact given to the res ipsa loquitur case is merely to permit an inference of negligence. ${ }^{34}$ In the following

868; Burghardt v. Detroit United R. Co., 206 Mich. 545, I73 N.W. 360, 5 A.L.R. I333. But see Waidleich v. Andros, I82 Mich. 374 , 148 N.W. 824 (where the term "res ipsa loquitur" is used in the opinion).) This statement, however, in conformity with the rule as generally applied, is apparently, and in effect, but a repudiation of the doctrine as construed to raise a presumption of negligence from the mere occurrence of the injury, rather than an actual repudiation of the principles upon which the doctrine is based. For, notwithstanding the denial of the doctrine, those principles which in other jurisdictions are embraced within, and designated as, the rule of res ipsa loquitur, are recognized and applied by the courts of this state, although only as rules of circumstantial evidence, (Loveland v. Nelson, 235 Mich. 623, 209 N.W. 835; Fuller v. Magatti, 23I Mich. 213, 203 N.W. 868; Burghardt v. Detroit United Ry. Co., 206 Mich. 545 , I 73 N.W. 360,5 A.L.R. I333.) so as to raise a presumption or permit an inference of negligence in cases where the circumstances involved are such as would otherwise be within the application of the rule."

${ }^{28}$ Keithley v. Hettinger, I33 Minn. 36, r 57 N.W. 897 (I916); Kleinman v. Banner Laundry Co., I5o Minn. 515, I86 N.W. I23 (x921); Ryan v. St. Paul Union Depot Co., I68 Minn. 287, 210 N.W. 32 ( $x_{926}$ ); Swenson v. Purity Baking Co., I83 Minn. 289, 236 N.W. 3ro (I93I); Vergeldt v. Hartzell, I F. (2d) 633 (I924).

${ }^{29}$ Dennery v. Great Atlantic \& Pacific Tea Co., 82 N.J.L. 5x 7, 8I Atl. 86r (rgIr); Hughes v. Atlantic City, 85 N.J.L. 212, 89 Atl. 769 (rgr 4 ); Sheridan v. Arrow Sanitary Laundry Co., I46 Atl. IgI (N.J. I929); Sheridan v. Foley, 58 N.J.L. 230, 33 Atl. 484 (I895).

${ }^{30}$ Womble v. Merchants' Grocery Co., I35 N.C. 474, 47 S.E. 493 (I904); Lyles v. Brannon Carbonating Co., I40 N.C. 25,52 S.E. 233 (Ig05); Modlin v. Simmons, I83 N.C. 63 , IIO S.E. 66r (I922); Harris v. Mangum, I83 N.C. 235, III S.E. I77 (I922).

${ }^{3 x}$ Glowacki v. Northwestern Ohio Ry. \& Power Co., II6 Ohio St. 45x, I57 N.E. $2 x$ (I927).

32 Sand Springs Park v. Schrader, 82 Okla. 244, rg8 Pac. 983 (rg2x). See I2 Cal. L. Rev. I4O (I924).

33 Something more is required by some courts for a directed verdict. See Giles v. Giles, 204 Mass. 383 (rgro) 90 N.E. 595; Sunderland, Directing a Verdict, II Mich. L. Rev. 198 (r9I3).

34 How much evidence the defendant must introduce in order to overcome the presumption is a matter which will be discussed later. 
states the res ipsa case has sometimes been treated as establishing a presumption: California, ${ }^{35}$ Kentucky, ${ }^{36}$ Illinois, ${ }^{37}$ Iowa, ${ }^{38}$ Louisiana, ${ }^{39}$ Missouri, ${ }^{40}$ New York, ${ }^{41}$ Pennsylvania, ${ }^{42}$ and South Carolina. ${ }^{43}$

What is the quantum of evidence required of defendant to overcome the presumption when such is raised by a res ipsa loquitur case? It should be borne in mind that in such a case the probative effect or logical cogency of the plaintiff's case before the defendant introduces any evidence is one which would warrant the jury finding for the plaintiff, though it might, of course, find for the defendant. The cases are uniform in requiring for the application of the res ipsa loquitur case a setup from which it is reasonably inferable that the injury would not have happened without negligence on the part of the defendant. It seems clear that the defendant ought not to escape a directed verdict against him by merely introducing some evidence. It should at least be credible and have some probative force. As to how much, there is little or no indication in the cases. ${ }^{44}$

(c) Shifts Burden of Introducing Evidence or Burden of Proof. While there are many unguarded statements to the effect that the application of the rule of res ipsa loquitur shifts the burden of proof upon the defendant, some of these expressions are made without observing the distinction between the shifting of the burden of going forward with evidence and the shifting of the burden of proof or persuasion proper. In several cases where the distinction is observed, the courts have held that while the bur-

35 Bush v. Barnett, 96 Cal. 202, 3 I Pac. 2 (I892); Green v. Pacific Lumber Co., I3o Cal. 435, 62 Pac. 747 ( 1900 ); Judson v. Giant Powder Co., ro7 Cal. 549, 40 Pac. ro20 (1895); Lejeune v. General Petroleum Corp., r28 Cal. App. 404, $x_{3}$ P. (2d) I057 (1932).

${ }^{36}$ Quillen v. Skaggs, 233 Ky. I7I, 25 S.W. (2d) 33 (I930).

37 Everett v. Foley, I32 Ill. App. 438 (I907).

${ }^{38}$ Fitch v. Mason City Traction Co., 124 Iowa 665, 100 N.W. 618 (1904); Weber v. Chicago R.I. \& P.R. Co., I75 Iowa 358, I5I N.W. 852 (I915); Arnett v. Ill. Central Ry., I88 Iowa 540, 176 N.W. 322 (1920).

39 Motor Sales \& Service v. Grasselli Chemical Co., I5 La. App. 353, I3I So. 623 (I930).

${ }^{40}$ Brown v. Consolidated Light, Power \& Ice Co., 137 Mo. App. 718, rog S.W. I032 (1908); Myers v. City of Independence, I89 S.W. 816 (Mo. I9I6). But see Brown-Scott v. Davis, 216 Mo. App. 530, 270 S.W. 433 (1925), approving Sweeney v. Erving, 228 U.S. 233, 33 Sup. Ct. 416, 57 L.Ed. 815 (1913).

45 Barkeley Scow Corporation v. G. V. Petrie \& Son, 37 F. (2d) 58 (r93o); Goldstein v. Levy, 74 Misc. 463 , I32 N.Y.S. 373 (r9II); Storms v. Lane, 223 App. Div. 79, 227 N.Y.S. 482 (1928); Loudoun v. Eighth Avenue Ry. Co., I62 N.Y. 380, 58 N.E. 988 (rgoo); Plumb v. Richmond Light \& Ry. Co., 233 N.Y. 285, 135 N.E. 504 (1922).

${ }^{42}$ Folk v. Schaeffer, I86 Pa. 253, 40 Atl. 4 OI (I898); Durning v. Hyman, 286 Pa. 376, I33 Atl. 568 (1926).

${ }_{43}$ Sullivan v. Charleston \& W.C.Ry. Co., 85 S.C. $53^{2}, 67$ S.E. $9{ }_{5}$ (19ro). Shelton v. S. P. Co., 86 S.C. 98,67 S.E. 899 (rgro).

14 The amount that should be required is discussed infra, $53^{\mathrm{I}}-535$. 
den of going forward shifted to defendant, the burden of proof did not.45 However, there are a respectable number of courts which have held that the burden of proof proper shifted. ${ }^{46}$.

\section{EFFECT OF PLEADING SPECIFIC ACTS OF NEGLIGENCE UPON THE USE OF RES IPSA LOQUITUR}

Under a general allegation of negligence the plaintiff may prove negligence by introducing enough evidence to make out a res ipsa loquitur case, the plaintiff not being in possession of direct evidence of negligence, is permitted to rely upon the res ipsa loquitur rule, and make out a case from which negligence may be inferred. If the plaintiff instead of a general allegation of negligence in his complaint sets out specific negligent acts or omissions, the doctrine of res ipsa loquitur does not apply. ${ }^{47}$ Thus in a case where the defendant carelessly and negligently parked his automobile so that it rolled down a grade and struck the plaintiff who was engaged in working on the street, and the complaint alleged that at the time the defendant parked said automobile he so carelessly and negligently applied the brakes of the said automobile as to permit said automobile to roll down said slope and strike the plaintiff and there was no pleading of general negligence, it was held improper to instruct the jury with respect to the res ipsa loquitur rule..$^{8}$ What is the effect of alleging specific acts of negligence after sufficient general allegations have been set out to permit proof of a res ipsa loquitur case? Must the plaintiff now rely wholly upon establishing the specific acts of negligence alleged or may he rely on his res ipsa loquitur case to establish the allegations of general negligence?

${ }_{45}$ See notes 53 A.L.R. I494, 59 A.L.R. 486, I6 I.R.A. (N.S.) 527, A.L.R. I9I6A, 930; Valente v. Sierra Railway Co., I5 I Cal. 534, 9r Pac. 48r (I907); Lejeune v. Gen. Petroleum Corp., I28 Cal. App. 404, I3 P. (2d) I057 (I932); Crooks v. White, I07 Cal. App. 304, 290 Pac. 497 (1930); Diller v. Northern Cal. Power Co., r62 Cal. 53I, r23 Pac. 359 (I9r2); Phillipsen v. Hunt, I29 Ore. 242, 276 Pac. 255 (I929); Eaker v. International Shoe Co., I99 N.C. 379, I54 S.E. 667 (I930).

${ }^{46}$ Montgomery \& Eufaula Ry. v. Mallette, 92 Ala. 209, 9 So. 363 (r89 I); Jacks v. Reeves, 78 Ark. 426, 95 S.W. 78 I (Ig06); Bush v. Barnett, 96 Cal. 202, 3 I Pac. 2 (I892); Green v. Pac. Lumber Co., I30 Cal. 435, 66 Pac. 747 (I900). [But see Valente v. Sierra Railway Co., ${ }_{5}{ }^{\mathrm{r}}$ Cal. 534, 9r Pac. 48I (I907) and Lejeune v. General Petroleum Corp., I28 Cal. App. 404, I3 P. (2d) I057 (I932)]; Weber v. Chicago R.I. \& Pac. Ry., I75 Iowa 358, I5 I N.W. $85^{2}$ (IgI6); Jones v. Pelley, I28 S.W. 305 (Ky. x9ro); Pindell v. Rubenstein, I39 Md. 567, II 5 Atl. 859 (I921); Bond v. St. Louis-San Francisco Ry., 315 Mo. 987, 1002-4, 288 S.W. 777 (x926); Johns v. Pennsylvania R. Co., 226 Pa. 3I9, 75 Atl. 408 (I9I0); Sullivan v. Charleston \& W.C. Ry. Co., 85 S.C. 532,67 S.E. 905 (rgro); Shelton v. Southern Ry. Co., 86 S.C. 98,67 S.E. 899 (I9I0); Washington-Virginia Ry. Co. v. Bouknight, II 3 Va. 696, 75 S.E. I032 (IgI2); Johnson v. Grays Harbor R. \& Light Co., I42 Wash. 520, 253 Pac. 819 (I927).

${ }^{47}$ Queirolo v. Pacific Gas \& Electric Co., Ir4 Cal. App. 6Io, 300 Pac. 487 (I93I).

48 Porter v. Rasmussen, I27 Cal. App. Dec. 405, r5 P. (2d) 888 (r932). 
Apparently three answers have been given to this question in the cases. In some jurisdictions allegations of specific acts of negligence preclude the plaintiff's making use of the doctrine. ${ }^{49}$

Other jurisdictions take the view that the additional allegations of specific acts of negligence in no way affect the plaintiff's right to rely upon his res ipsa loquitur case. s $^{\circ}$

A third view is that of a compromise between these two extremes by which the plaintiff will not be deprived entirely of his use of the res ipsa loquitur case by alleging specific acts of negligence. He may use the res ipsa loquitur case to establish the existence of the acts of negligence, alleged specifically. Thus, in Atkinson $v$. United Railroads of San Francisco, ${ }^{5 x}$ in an action for the death of a passenger, the street car in which he was riding struck a truck. In addition to general allegations of negligence, the complaint charged specific acts of negligence against the street car company in that its car was being carelessly operated at an excessive rate of speed in violation of the municipal ordinance and without any notice or warning of its approach. The court held that this did not deprive the plaintiff of the use of the doctrine of res ipsa loquitur, since all the evidence shown and which established the res ipsa loquitur case only went to prove the allegations of specific acts of negligence..$^{2}$

The argument generally advanced in favor of not permitting the plaintiff to make use of his res ipsa loquitur case where he alleges specific acts of negligence is that since the doctrine of res ipsa loquitur rests upon the fact that presumptively the facts are not accessible to the plaintiff but are accessible to the defendant, the law should relieve the plaintiff from, and shift over to the defendant, this burden of producing the evidence. When the plaintiff goes forward and alleges specific acts of negligence on the part of the defendant, this demonstrates that the facts are accessible to the plaintiff and the basis for invoking the res ipsa loquitur doctrine no longer exists.

49 Chicago Union Traction Co. v. Leonard, I 26 IIl. App. I89 (rgo6); Byland v. E. I. Du Pont de Nemours, 93 Kan. 288, I44 Pac. 25I (I9I4); Cooper v. Century Realty Co., $224 \mathrm{Mo.}$ 709, I23 S.W. 848 (Igog); Orcutt v. Century Bldg. Co., 20I MIo. 424, 443, 99 S. W. 1062 (I907); Ft. Worth Railway Co. v. Neal, r4o S.W. 398 (Tex. IgrI).

so Firszt v. Capitol Park Co., 98 Conn. 627, 120 Atl. 300 , 29 A.L.R. 17 (1923); Cassady v. Old Colony Railway Co., I84 Mass. I56, 68 N.E. Io (I903); Washington-Virginia Railway Co. v. Bouknight, II3 Va. 696, 75 S.E. I032 (I9I2); Walters v. Seattle Ry. Co., 48 Wash. 233, 93 Pac. 4I9 (rgo8).

${ }_{5 x}$ Atkinson v. United Railroads of San Francisco 7 Cal. App. 82, 234 Pac. 863 (1925).

${ }^{2}$ For other cases adopting this compromise rule, see Palmer Brick Co. v. Chenall, $1 x_{9} \mathrm{Ga}$. 837,47 S.E. 329 (I904); Terre Haute \& I. RR. Co. v. Sheeks, I55 Ind. 74, 56 N.E. 434 (I900); Sutton v. So. Ry. Co., 82 S.C. 345,64 S.E. 401 ( $19 \circ 9$ ); see also, note in $1_{3}$ Cal. L. Rev. 424 (rg25), on the Effect of Alleging Specific Acts of Negligence on the Use of the Res Ipsa Loquitur Case. 
If the res ipsa loquitur doctrine is treated as having the effect merely of laying the basis for a permissible inference by the jury of negligence on the part of the defendant, it would certainly seem unfair to the plaintiff if he has facts which establish a case having the probative value warranting an inference of negligence, that he should be deprived of it if he goes a little further and makes allegations of specific acts of negligence and attempts to rest his case on such ground as well as upon general allegations, that is, upon the res ipsa loquitur case. It seems a strange doctrine which would deprive the plaintiff of the use of evidence of sufficient probative value to establish his case, merely because he exhibits the hope that he may be able to rest his case also on other evidence. It seems, too, that we should not have a system of justice which takes away from the courts this evidence so essential in determining justice between the parties. It would therefore seem that in a jurisdiction which treats the res ipsa loquitur case as merely raising a permissible inference of negligence it is sound to allow the plaintiff, to allege both general and specific acts of negligence, and to rely upon both or either as the case develops. The compromise view set out in the Atkinson case seems as unwarranted as the view which denies all use of the res ipsa loquitur case where the complaint contains allegations of specific acts of negligence, and besides, it has the grave defect of adding the difficulty of determining when the evidence establishing the res ipsa case does not go beyond showing the existence of the specific acts of negligence alleged which would forfeit its use.

In this connection, a general principle of pleading that specifications of negligence set out in a complaint control all general allegations and limit the proof at the trial to the acts specified, must be recognized as a sound rule of law, at least in so far as such principle of pleading rests upon the doctrine that the plaintiff must not take the defendant by surprise. But where the surprise element is avoided by setting out the specifications of negligence, not as explanations of a general allegation, but as further specified acts of which the more general allegation is only the first, ${ }^{53}$ or where the general allegations of negligence are set out in one count and the specific allegations are set out in another, so that there is no possibility of the defendant fairly complaining of surprise, there seems to be no basis whatever for depriving the plaintiff of his right to rely upon the res ipsa loquitur case to establish negligence, merely because he has set out in his complaint specific acts of negligence.

Where the rule of res ipsa loquitur is treated not merely as laying the basis for a permissible inference but as having something more than its

53 Clark, Code Pleading (I928), 208. 
probative value, by reason of the fact that the evidence concerning the injury is presumably accessible to the defendant and not to the plaintiff, and for that reason the burden is passed over to the defendant and the plaintiff relieved of it, there may be more basis for the view which deprives the plaintiff of his use of the res ipsa loquitur case when he has alleged specific acts of negligence. For, by alleging the specific acts of negligence, he has shown that these facts which were presumably accessible only to the defendant are also accessible to him, and in so far as the doctrine has artificial force, that is, that it requires an assumption of facts beyond that required by logical inference, it would not be unfair to deprive the plaintiff of that advantage.

However, in any case, a plaintiff should never be deprived, in the absence of surprise upon the defendant or for some other valid reason, of the probative force of any case he may be able to establish, merely by reason of the fact that he has pleaded specific acts of negligence. This rule that an allegation of specific acts of negligence deprives the plaintiff of his res ipsa loquitur case, as has been ably pointed out, is valuable to a defendant, not because it protects him from surprise, but because it gives him an opportunity to catch an unwary opponent in a damaging error. ${ }^{54}$

\section{CRITICISM OF RES IPSA LOQUITUR}

(a) Where it is given the effect of a permissible inference. The res ipsa loquitur case has no excuse for existence if it is to be treated as having the effect merely of laying the basis for a permissible inference of negligence. One set of circumstances universally required in a res ipsa loquitur case is that the facts warrant a reasonable inference of negligence on the part of the defendant. But if the circumstances shown are sufficient to warrant an inference of negligence, why require the further showing of an instrumentality in the exclusive control and possession of the defendant, and that there was no voluntary action on the part of the plaintiff? Should evidence which reasonably warrants an inference of negligence be excluded because further facts cannot be shown? Is the res ipsa loquitur case another situation to which the best evidence rule extends, nay, where we go further and deny the use of competent and adequate circumstantial evidence, even when direct evidence is not available, because certain other circumstantial evidence is not shown? No such distinction between direct and circumstantial evidence is made elsewhere in the law. It seems highly technical and unjust to refuse the plaintiff the use of evidence which might in some cases, clearly, and in others, in all probability, establish his case. It seems clear that the court should have this material to aid it in ascertaining

54 Niles, Pleading Res Ipsa Loquitur, 7 N.X. Univ. L. Quar. 4×5 (r929). 
the truth. Nevertheless, the evidence is not available to the plaintiff if a single one of the technical requirements laid down by the rule is not present.

Another effect of the rule is to divert the mind of the court and counsel from the truly material issues in the case in order to discover whether the technical requirements exist. For instance, the inquiry may turn on whether the defendant has or has not exclusive possession of the instrumentality causing the injury, and that in a case, too, where it seems proper to hold the defendant to liability without showing he had control or possession of the instrumentality which caused the injury. ${ }^{55}$ Has a railway company sufficiently exclusive possession of its tracks and switches to satisfy this requirement? Any test to determine that fact other than whether under the facts of the particular case the inference may reasonably be made that the injury arose from the negligence of defendant's servants, seems futile.

Further, as has been pointed out,,$^{56}$ there is frequently great difficulty in determining whether the evidence shows specific acts of negligence or merely evidence to establish a res ipsa loquitur case. For example, where a dentist's drill slipped from the plaintiff's tooth and lacerated his mouth..$^{57}$ Is that a specific act of negligence or a case for the application of res ipsa loquitur? Such inquiry ought to be useless. It should be enough if from the facts it is reasonably inferable that the injury resulted from defendant's negligent act or omission.

(b) Where it is given the effect of a presumption. If, on the other hand, the res ipsa loquitur doctrine involves something more than a permissive inference to be made from the evidence introduced, that is, if it may have some artificial weight, if the law requires the assumption of negligence on the part of the defendant on the production of evidence making out a res ipsa loquitur case in the absence of any evidence in opposition by the defendant, there seems to be more justification for a rule of res ipsa loquitur with its technical requirements. Presumption is here used to mean a rule of law relating to proof that requires the assumption that a fact exists on the proof of another fact or group of facts. The existence of such fact may not always be logically inferable from such fact or group of facts. The fact or facts proved may be given a purely logical effect or both a logical and artificial effect, or a purely artificial effect in assuming the existence of the other fact. The artificial effect given the evidence in the res ipsa case rests

ss See note, 4 So. CaI. L. Rev. 400 (rg3r), on Motor Sales \& Service, Inc., v. Grasselli Chemical Co. ${ }_{5}$ La. App. 353 , I3r So. 623 (I930).

${ }^{56}$ Supra, 526.

57 Vergeldt v. Hartzell (C.C.A. 8th I924), I F. (2d) 633; Vale v. Noe, I 72 Wis. 42 I, 179 N.IV. 572 (x920). 
upon the defendant's greater accessibility to certain facts and justifies the shifting of the burden at least with respect to producing the evidence as to these facts upon the defendant. Too, there is a basis for the position that the plaintiff's pleading special acts of negligence should deprive him of the use of the res ipsa loquitur case, for by so pleading he has shown that the evidence is probably not inaccessible to him. However, in such case, the plaintiff should not be robbed of any more than the artificial weight which the law gives to the res ipsa loquitur case, and he, therefore, should not be deprived of his opportunity to rely upon the case for the purpose of going to the jury, but only be denied the effect of the presumption.

As to the quantum of evidence required of the defendant to rebut the presumption of negligence raised by establishing a res ipsa loquitur case, the decisions shed little light. Of course the effectiveness of a presumption may vary with respect to the degree of proof required of the plaintiff to establish his case in the absence of a presumption, that is, whether the plaintiff is required to establish the facts at issue beyond a reasonable doubt, as is required of the state in criminal cases, or whether he has done enough to persuade the jury that it is more likely than not that the facts upon which his case rests exist, or whether he must go further and establish the facts of his case by clear and convincing evidence although it falls short of establishing conviction beyond a reasonable doubt. In most jurisdictions, only the intermediate degree of proof, namely, that it is more likely than not that the fact exists, is required of the plaintiff in negligence cases. We confine our discussion to cases requiring that intermediate degree of proof.

A variety of effects have been given to presumptions..$^{58}$ In considering

58 Professor Edmund M. Morgan, in a very thorough discussion of Burden of Proof, in 47 Harv. L. Rev. 59 (r933), has summarized these effects as follows: "Each of the following opinions has some express judicial sanction. (I) A presumption puts upon the opponent the burden of producing evidence which would justify a reasonable jury in finding against the presumed fact; only this and nothing more. (2) It places upon the opponent the burden of persuading the jury to believe so much of the evidence against the presumed fact as would justify a reasonable jury in finding against the fact. The effect upon the mind of the particular jury as to the existence or non-existence of the presumed fact is immaterial. (3) It places upon the opponent the burden of persuading the jury not to disbelieve so much of the evidence against the presumption as to leave the remainder insufficient to justify a reasonable jury in finding against the presumed fact. In other words, the presumption will lose all efficacy even though the jury positively believes none of such evidence, positively discredits a portion of it, and is unable to determine whether to believe or disbelieve the remainder of it, provided only that such remainder is of the requisite quantity and quality to justify a reasonable jury in finding the non-existence of the presumed fact. Again, the effect of the evidence upon the opinion of the particular jury as to the existence of the presumed fact is immaterial. (4) It puts upon the opponent the burden of persuading the jury that the existence of the presumed fact is so doubtful that the jury cannot determine whether it exists. Beginning with the assumption that the 
the effect that should be given to the presumption in the res ipsa case, we discuss briefly five effects that may be given to presumptions in general and in the following hierarchy, beginning with the least effect: First, the presumption is rebuttable by defendant by some evidence though it is without weight or credibility in negativing defendant's negligence; second, by evidence which, taken with the plaintiff's case, would justify a jury in finding that the defendant was as likely not negligent as negligent; third, by evidence from which a jury, beginning with the assumption that the defendant was negligent in causing the plaintiff's injury, might reasonably find that the defendant was as likely not negligent as negligent; fourth, by evidence establishing certain facts, such as "what actually occurred" or "how it happened"; and fifth, by evidence sufficient to convince the jury that the defendant was more likely not negligent than negligent.

It would seem improper to permit the defendant to escape the effect of the presumption by merely introducing some evidence. To require no more establishes a distinction between permissible inference and presumption which is without practical significance and all the objections that may be urged against treating the res ipsa loquitur case as merely raising a basis for a permissible inference can be urged against it, plus the objection of allowing a farcical procedure to produce important consequences. To permit a defendant to escape liability by introducing evidence without convincing power also encourages perjury. ${ }^{59}$

It would seem too clear for argument that the evidence required of the defendant to overcome the presumption in favor of the plaintiff should at least have some persuasive power in rebuttal of the fact of negligence which the law presumes. How great a persuasive force must it have? The least probative force required of the plaintiff to make out a res ipsa loquitur case is one from which the judge may infer that a jury might reasonably

presumed fact does exist, the jury must by the evidence be put in such a state of mind that they cannot say whether it exists or not. (5) It puts upon the opponent the burden of persuading the jury that the presumed fact does not exist. (6) In addition to one of the foregoing, the jury must also consider the presumption as evidence or with the evidence in its process of determining whether or not the presumed fact exists. (7) Each of these six views assumes that a presumption compels the trier upon the establishment of a given fact to assume the existence of another fact. The term is sometimes used to express the idea that the trier will be permitted to deduce from the existence of a particular fact the existence of another, even though ordinary human experience as revealed in judicial experience might not justify such a deduction. (8) Finally the term is employed with the adjective 'conclusive' to denote a positive rule of law, either substantive or procedural, which no evidence to the contrary can overthrow. Insofar as a presumption affects the activities of the jury in their consideration or decision of issues, it is essential that they be advised of its influence in intelligible language."

${ }^{59}$ McIver v. Schwartz, 50 R.I. 68, I45 Atl. Ior (I929); Pariso v. Towse, 45 F. (2d) 962 (1930); Morgan, Presumptions and Burden of Proof, 47 Harv. L. Rev. 59, 80 (1933). 
infer negligence on the part of the defendant as the cause of the plaintiff's injury. Now to require no more of the defendant than the introduction of evidence of such persuasive force that it would convince the judge that the jury might reasonably find from the whole case (the plaintiff's and defendant's) that defendant was as likely not negligent as negligent would be requiring no more than the introduction of some evidence, no matter how infinitesimally persuasive it might be. The requirement would be substantially the same as requiring the introduction of evidence without persuasive force.

Going upward in the hierarchy of persuasiveness of proof, the next practicable step would be to throw the burden on the defendant of convincing the judge that a jury might, assuming the presumed fact of defendant's negligence, in the absence of any rebutting testimony, to be true, reasonably find from the defendant's testimony that the defendant was more probably not negligent than negligent, or as likely not negligent as negligent. This would not conflict with the dogma that the burden of proof does not shift. But this dogma has been shown to be without merit and to be disregarded in determining the effect to be given to presumptions. The persistence of a presumption should depend upon the considerations which gave rise to it. ${ }^{60}$ While this somewhat complicated test might be useful to the judge in deciding whether to direct a verdict for the plaintiff or not, it is very questionable whether it could be made effective as a guide in an instruction to the jury. If we are inclined to place a high estimation upon the discriminatory powers of the ordinary jury and admit the test is a practicable one, it may still be objected that it can not be as clear to a jury as throwing the burden of proof of absence of negligence on the defendant, and there is no practically workable test between these two. It has been urged that the purpose of the presumption is satisfied when the defendant introduces evidence of "what actually took place" or how it happened. ${ }^{6}$ The argument is that the presumption was created to relieve the plaintiff of the disadvantage he was under as respects accessibility to the evidence and when such evidence is introduced the position of the parties is equalized and to carry the presumption farther places the plaintiff at an unfair advantage over the defendant. There are several objections to this method of handling the presumption. First, the defendant in a large number of cases does not know "what took place" or "how it happened" and

\footnotetext{
${ }^{60}$ Morgan, Presumptions, 44 Harv. L. Rev. go6 (r93r); Morgan, Presumptions and Burden of Proof, 47 Harv. L. Rev. 59 (I933); Bohlen, The Effect of Rebuttable Presumptions of Law Upon the Burden of Proof, 68 Univ. of Pa. L. Rev. 307 (I920); Chaffee, The Progress of the Law, 35 Harv. L. Rev. 302, 313 (I922), 33 Harv. L. Rev. 306 (Igrg).

${ }^{6 r}$ Bohlen, Rebuttable Presumptions of Law, 68 Univ. of Pa. L. Rev. 307, 315 (r920); Studies in the Law of Torts (1926), 636,645; Harper, Law of Torts (1933), I85-6, $\$ 77$.
} 
can introduce no evidence as to such fact. The defendant's rebuttal evidence in most res ipsa cases consists in showing due care on his part and on the part of his servants as respects the construction, inspection and user of the appliance which caused the injury. It is only by inference from evidence of this sort that the defendant can be said to show how it happened. It seems clear that when such evidence is introduced by the defendant it must be weighed as to its probative force in establishing absence of negligence on the part of the defendant. We cannot lay down a rule that when the defendant has introduced evidence as respects his care in the construction, inspection, and user of the appliance, he has proved anything, much less that he has met the plaintiff's case. This method of handling the presumption is also wrong in assuming that the basis of raising a presumption in the res ipsa loquitur doctrine rests upon the plaintiff's inaccessibility to the evidence. It also rests upon the further basis that the plaintiff has established a case of injury which usually results only from the defendant's negligence. The plaintiff has made out a case both in law and in fact against the defendant unless the defendant rebuts it. The impracticability of rebutting the presumption in this way can easily be imagined if one will simply take a few concrete cases and consider the complicated character of the jury instructions that would be needed to give it effect.

Finally, what are the arguments for and against giving the effect to the presumption of casting upon the defendant the full burden of persuasion of the jury that he was more likely not negligent than negligent? Against giving such effect to the presumption, it is urged that it violates the rule that the burden of proof never shifts but only the burden of producing evidence and, second, that it is unfair to the defendant. In favor of giving this effect to the presumption, it may be urged that it is the most practicable and workable and that it more nearly accomplishes the purpose for which the presumption exists.

The dogma that the burden of proof never shifts has been shown to be inapplicable where presumptions are involved. ${ }^{62}$ It is somewhat inaccurate to use the distinction "burden of going forward with the evidence" and "burden of proof." Wherever the defendant is required to introduce evidence, it always casts upon him a burden of proof to some extent of something, and it is to prove something that he is required to introduce evidence. It is after all merely a gradation of burdens of proof with which we deal. The burden of proof cast on the defendant by a presumption might be merely to convince the judge that a jury might find from his evidence

${ }^{62}$ See supra note 60. 
that the existence of the presumed fact was made doubtful, or it might be the so-called full burden of persuading the jury that the presumed fact did not exist or proof of something intermediate between the two. The expression "burden of producing evidence," without more is unintelligible. It must be a burden of proof to some extent of something and for some purpose. The burden of proof of negligence which ordinarily rests upon the plaintiff is not a burden of proof of negligence to the fullest extent, namely, beyond a reasonable doubt, but only to the extent that the jury may be satisfied that it is more likely than not that the defendant was negligent. There is nothing inherent in the concept of burden of proof that prevents it from being shifted from the party upon whom the law originally placed it. It should be shifted if the convenience of trial or reason or justice dictates.

Is it unfair to the defendant, where the plaintiff has established a res ipsa loquitur case, to require him to assume the burden of introducing evidence sufficient to satisfy the jury that it is more likely than not that the defendant was free from negligence? There are two considerations behind the requirement that the defendant assume some burden of proof. One is that the facts relating to his having a negligent relation to the injury are ordinarily more accessible to the defendant since he has the exclusive possession and control of the appliance whose operation caused the plaintiff injury, and the other is that the appliance would not ordinarily produce injury unless there was negligence on the part of the defendant as to the construction, inspection or user of the appliance. Under such circumstances, is it unfair to require the defendant to show that it was more likely than not that the unusual happened in the particular case?

To cast the so-called full burden of persuasion on the defendant is clearly the simplest and most easily understood method of handling a complicated case before the jury. Where the plaintiff has established a res ipsa loquitur case and the defendant has put in his rebuttal the jury can be instructed to find for the plaintiff unless they are satisfied that it is more likely that defendant was not negligent than that he was. Any less burden thrown on the defendant complicates the handling of the case with the jury. To cast the full burden of proof on the defendant seems to best accomplish the purpose for which the presumption exists. The defendant has access to the facts which show his absence of negligence if he is innocent and his guilt if he is not, while the plaintiff who has shown that the injury could not ordinarily have happened unless the defendant was negligent has ordinarily no chance to rebut the defendant's case. To throw the full burden of persuasion onto the defendant would seem more likely to secure justice in the larger portion of the cases. 